\title{
Villemonte's approach: a general method for modeling uniform and non-uniform performance in stepped fishways
}

\author{
Juan Francisco Fuentes-Pérez ${ }^{1, *}$, Ana García-Vega ${ }^{2}$, Francisco Javier Sanz-Ronda ${ }^{2}$ \\ and Andrés Martínez de Azagra Paredes ${ }^{2}$ \\ ${ }^{1}$ Centre for Biorobotics, Tallinn University of Technology, Akadeemia tee 15A-111, 12618 Tallinn, Estonia \\ 2 Department of Hydraulics and Hydrology, ETSIIAA, University of Valladolid, Avenida de Madrid 44, Campus La Yutera, \\ 34004 Palencia, Spain
}

\begin{abstract}
Stepped fishways are the most popular solutions to enable the free movement of fish fauna through weirs and dams. Given the flow variation of rivers throughout the year, successful fish migration through stepped fishways relies on the accurate discharge calculation and their modeling under variable scenarios. This study aims to propose a general method for flow and water level calculation of stepped fishways, unifying different findings in specialized literature. To achieve this purpose, the relation defined by Villemonte is used and tested under laboratory and field case studies. This study shows that the hydraulic behavior of a wide range of stepped fishway typologies can be explained based on a single equation, as well as the need of calibration of the coefficients involved in this equation for different subtypes. Furthermore, the proposed method enables the water level modeling under variable boundary conditions, which in turns allows the analysis of stepped fishways hydraulic performance under different river scenarios. The comparison of the hydraulic parameters in the fishways with the physical capacities and preferences of fish will contribute to the fulfillment of their main objective: allow free movement of fish fauna.
\end{abstract}

Keywords: discharge coefficient / flow measurement / vertical slot fishway / pool and weir fishway / nature-like fishway

\begin{abstract}
Résumé - L’approche de Villemonte : une méthode générale de modélisation de la performance uniforme et non uniforme dans les échelles à poissons. Les échelles à poissons sont les solutions les plus populaires pour permettre la libre circulation de la faune piscicole à travers les seuils et les barrages. Compte tenu de la variation de débit des cours d'eau tout au long de l'année, la migration réussie des poissons par ces passes à poissons repose sur le calcul exact de la décharge et sa modélisation dans des scénarios variables. Cette étude a pour but de proposer une méthode générale de calcul du débit et du niveau d'eau des échelles à poissons, synthétisant différents résultats de la littérature spécialisée. Pour atteindre cet objectif, la relation définie par Villemonte est utilisée et testée dans des études de cas en laboratoire et sur le terrain. Cette étude montre que le comportement hydraulique d'une large gamme de typologies de poissons en gradins peut être expliqué sur la base d'une seule équation, avec besoin d'étalonnage des coefficients impliqués dans cette équation pour différents sous-types. De plus, la méthode proposée permet de modéliser le niveau de l'eau dans des conditions aux limites variables, ce qui permet, à son tour, d'analyser la performance hydraulique des passes de poissons en escaliers selon différents scénarios de rivières. La comparaison des paramètres hydrauliques dans les passes à poissons avec les capacités physiques et les préférences des poissons contribuera à la réalisation de leur objectif principal : permettre la libre circulation de la faune aquatique.
\end{abstract}

Mots-clés : coefficient de décharge / mesure de débit / passe à fentes verticales / passe en bassins / passe de type rivière artificielle

\footnotetext{
* Corresponding author: juan.fuentes@ttu.ee
} 


\section{Introduction}

Humans have found in rivers a source to satisfy many of their basic necessities, which have resulted in their geomorphological and ecological alteration (Nilsson et al., 2005). One of the most notable alteration in rivers is the installation of cross-sectional structures (e.g. weirs and dams) to satisfy water and energy requirements or for flood control. These structures fragment the stream and can block the movement of some animals such as fish, which require different environments to complete their life cycles (Lucas et al., 2001; Branco et al., 2013). In recent years, ensuring undisturbed fish migration has become a key component of watershed restoration (Santos et al., 2014) and the installation of fishways is one of the most widely adopted solution in order to achieve this objective.

There are many types of fishways. The most common ones consist of a succession of cross-walls in a sloped channel, namely, stepped fishways or fish ladders (Fig. 1) (e.g. vertical slot fishway (VSF) (Rajaratnam et al., 1986; Larinier, 2002b; Fuentes-Pérez et al., 2014), pool and weir fishway (PWF) (Rajaratnam et al., 1988; Larinier, 2002b; Fuentes-Pérez et al., 2016), and step-pool nature-like fishway (SPNF) (FAO/ DVWK, 2002; Wang and Hartlieb, 2011)). These structures divide the total height of the obstacle $(H)$ in smaller drops $(\Delta H)$ in each cross-wall to ensure that the hydraulic conditions inside are in the range of the physical capacities of fish fauna and, thus, enable their passage.

Depending on the type of fishway, they can have different kinds (slots, notches, or orifices) and number of connections in the cross-walls between pools, from a single slot, like for example in some VSFs, to multiple combinations in SPNFs.

The discharge and performance of fishways can be modeled in many different ways, which enables the classification of these hydraulic calculations into two big groups: dimensionless relationships (Rajaratnam et al., 1986, 1989; Ead et al., 2004; Yagci, 2010) and classical weir equations (Larinier, 1992; Clay, 1995; Martínez de Azagra, 1999; Boiten and Dommerholt, 2006; Krüger et al., 2010). The first group of equations is only useful when $\Delta H$ is equal to the topographic difference between pools $(\Delta Z)$ (i.e. same water depth in all pools) (Rajaratnam et al., 1986). This is known as uniform regimen, which is difficult to achieve in field conditions due to the temporal variability of river flow (Fuentes-Pérez et al., 2016; Marriner et al., 2016). Regarding classical weir equations, the most commonly used equations are the orifice equations derived from Torricelli's law (Torricelli, 1644) as well as Poleni's weir equation (Poleni, 1717). An accurate selection of the discharge coefficients for these equations is vital in order to achieve precise results, both under uniform $(\Delta H=\Delta Z)$ as well as under non-uniform $(\Delta H \neq \Delta Z$ ) conditions. In order to use these equations under both conditions, it will be necessary to consider the water level upstream $\left(h_{1}^{\prime}\right)$ and downstream $\left(h_{2}^{\prime}\right)$ of the cross-wall (FuentesPérez et al., 2014).

Non-uniform performance in fishways is usually classified in two main different water level profiles (Rajaratnam et al., 1986): M1 or backwater profile, which produces higher mean depth $\left(h_{0}\right)$ and smaller drops $(\Delta H<\Delta Z)$ in the downstream pools of the fishway, and M2 or drawdown profile, which contrary, generates lower $h_{0}$ and higher drops $(\Delta H>\Delta Z)$ in downstream pools. It is likely to occur in field conditions due to the variable hydrological regimen of river or small deviances in the construction of the fishway (Fuentes-Pérez et al., 2016; Marriner et al., 2016). This will modify the hydrodynamics of the flow inside the fishway, which may lead to an incompatibility with fish fauna preferences or capabilities, affecting the efficiency of fish passage (Fuentes-Pérez et al., 2016; Sanz-Ronda et al., 2016). For instance, M1 profiles may improve the passability due to the lower velocities in the crosswalls or the reduction on the volumetric power dissipation $(V P D)$ within the pools, but it may decrease the attractivity due to reduction of velocity in the most downstream cross-walls. Contrary, M2 profiles may led to more attractive scenarios but may generate too demanding drops to be surpassed or conditions with too high VPD in downstream pools.

Thus, non-uniformity must be considered in fishway research. However, the simplification of the study of fishways is a widespread problem and, in many cases, their performance is modeled according to uniform conditions (Rajaratnam et al., 1986; Wu et al., 1999; Puertas et al., 2004; Bermúdez et al., 2010; Wang et al., 2010; Tarrade et al., 2011; among others).

Using some of the most extended fishway guidelines (Larinier, 1992; FAO/DVWK, 2002; Krüger et al., 2010) it is possible to explain, at least partly, the non-uniform performance. Likewise, some recent works have shown that it is possible to use classical weir equations together with the submerged weir discharge coefficient $\left(C_{S}\right)$ proposed by Villemonte (1947) to model fishway performance under uniform and non-uniform scenarios in specific subtypes of VSF (Fuentes-Pérez et al., 2014) and PWF (Fuentes-Pérez et al., 2016).

In the present paper, we study the use of Villemonte's equation as a general discharge coefficient definition for flow and water level calculation of all stepped fishway types under field conditions. This is achieved by calibrating the discharge coefficient for the different fishway types (PWF, VSF and SPNF) and subtypes (different morphologies within the types) studied in the field and in specialized literature, which will enable us to validate this general methodology. The main contributions of this paper are: to (i) prove the usefulness of Villemonte's equation as a general method for the estimation of stepped fishway discharge and water levels under uniform and non-uniform scenarios; (ii) adjust the coefficients of this equation for flow measurement in stepped fishway types and subtypes proposed by the specialized literature as well as field cases; and (iii) show that this equation is able to unify findings in different scientific references.

\section{Material and methods}

\subsection{Theoretical background: recommended discharge equations}

The performance and discharge of stepped fishways will be explained by means of classical weir equations. The equation for weirs proposed by Poleni (1717) (Eq. (1)) will be used to describe the flow $(Q)$ through notches (Larinier, 1992; Martínez de Azagra, 1999; FAO/DVWK, 2002) and slots (FAO/DVWK, 2002; Krüger et al., 2010). On the other hand, the orifice equation derived from Torricelli's law 

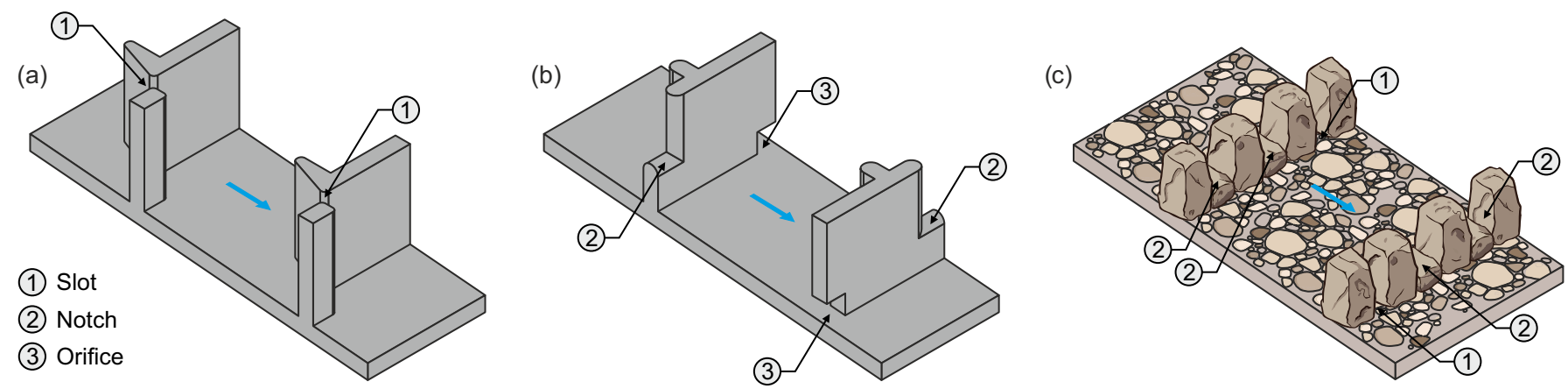

Fig. 1. Examples of sections of stepped fishways. Each type (a) vertical slot fishway, (b) pool and weir fishway and (c) step-pool nature-like fishway can have different subtypes according to their morphology and connections.

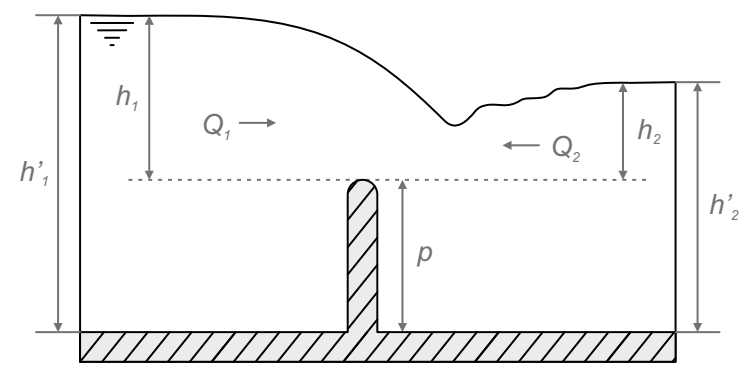

Fig. 2. Sketch of Villemonte's assumption for submerged flows. $Q_{1}$ is the free flow discharge in positive direction controlled by $h_{1}$ and $Q_{2}$ is the counter-flow discharge due to $h_{2} \cdot p=0$ in case of slots.

(Torricelli, 1644) (Eq. (2)) will be used to describe the $Q$ through orifices (Larinier, 1992; Martínez de Azagra, 1999; FAO/DVWK, 2002; Boiten and Dommerholt, 2006).

$$
\begin{aligned}
& Q=\frac{2}{3} \cdot C_{s} \cdot b \cdot h_{1}^{1.5} \cdot \sqrt{2 \cdot g}, \\
& Q=C_{o} \cdot b \cdot a \cdot \sqrt{2 \cdot g \cdot \Delta H},
\end{aligned}
$$

where $g$ stands for the gravity, $h_{1}$ is the water level upstream the cross-wall deducting the sill height $(p), b$ is the width of notches, slots or orifices, $a$ is the height of the orifice and $C\left(C_{s}\right.$ and $\left.C_{o}\right)$ stands for the discharge coefficients.

Multiple fishways studies have demonstrated that $C_{o}$ can be considered independent of the different water level variables involved $\left(\Delta H, h_{2}\right.$ and $h_{1}$, where $h_{2}$ is the water level downstream the cross-wall deducting $p$ ) (Brater et al., 1996; Boiten and Dommerholt, 2006; Fuentes-Pérez et al., 2016). This property is derived from equation (2) and, for this reason, it can be considered that $C_{o}$ will only vary according to the geometrical variables of the orifice (dimensions, shape and cross-wall thickness).

For slots and notches, Villemonte's submerged coefficient will be used as a generic discharge coefficient (Villemonte, 1947). Villemonte derived his coefficient assuming that $Q$ is the difference between the free-flow discharge due to $h_{1}\left(Q_{1}\right)$ and the counter-flow discharge due to $h_{2}\left(Q_{2}\right)$ (Fig. 2 and Eq. (3)).

$$
Q=Q_{1}-Q_{2} \rightarrow \frac{Q}{Q_{1}}=1-\frac{Q_{2}}{Q_{1}} .
$$

The experiments carried out by Villemonte confirmed this hypothesis, $Q / Q_{1}\left(C_{S}\right)$ is related functionally to $1-Q_{2} / Q_{1}$. Considering this and replacing $Q_{1}$ and $Q_{2}$ by equation (1), the final form of $C_{S}$ is obtained (Eq. (4)).

$$
\begin{aligned}
& C_{s}=\frac{Q}{Q_{1}}=\beta_{0}\left(1-\frac{Q_{2}}{Q_{1}}\right)^{\beta_{1}} \rightarrow \\
& \rightarrow C_{s}=\beta_{0}\left[1-\left(\frac{h_{2}}{h_{1}}\right)^{1.5}\right]^{\beta_{1}},
\end{aligned}
$$

where $\beta_{0}$ and $\beta_{1}$ are coefficients which depend on the geometry of the slot or notch, pool dimensions, and the discharge equation used. Villemonte concluded that $\beta_{1}$ was equal to 0.385 in all his experiments for submerged weirs, however he recommended its calibration for different setups. $\beta_{0}$ can be considered as a constant approximation of a free discharge coefficient.

\subsection{Hypothesis testing through case studies}

Data from peer-reviewed scientific studies, grey literature and from our own field experiments were used to test the hypothesis: Villemonte's equation can be adapted to model different types of stepped fishway under uniform and nonuniform conditions.

A systematic search was carried out following the PRISMA (Preferred Reporting Items for Systematic Reviews and Meta-Analyses) guidelines (Moher et al., 2009) (S1 Appendix). This systematic search was carried out in Google Scholar as well as in Web of Science and Scopus from conception to September 2016 for articles and grey literature on VSFs, PWFs and SPNFs. To standardize and minimize errors only studies containing raw data and appropriate geometrical descriptions were considered for calibrating purpose. This is rather difficult to find and, aside data from our own field tests, only references for VSFs were found useful (Rajaratnam et al., 1986, 1992; FAO/DVWK, 2002; Puertas et al., 2004) (Tab. 1). Likewise, as only English has been used for the search, this might have introduced a language bias.

Regarding field studies ( 8 in total), all the fishways are located in the basin of the Duero River, in North-Central Spain (Fig. 3). The Department of Hydraulics and Hydrology of the University of Valladolid was involved in the design of all of them. The information about location, characteristics and geometry of each fishway can be found in S2 Appendix. 
Table 1. Summary of collected data through references and field experiments.

\begin{tabular}{lll}
\hline Type & No. of data & Source \\
\hline VSF & 441 & Rajaratnam et al. (1986, 1992), FAO/DVWK (2002), Puertas et al. (2004) and 4 \\
& & field cases, 2 included in Fuentes-Pérez et al. (2014) \\
PWF & 180 & 3 field cases, 1 included in Fuentes-Pérez et al. (2016) \\
SPNF & 45 & 1 field case \\
\hline
\end{tabular}

A description of own field cases can be found in S2 Appendix and all data collected in field cases is included in S3 Data Appendix.

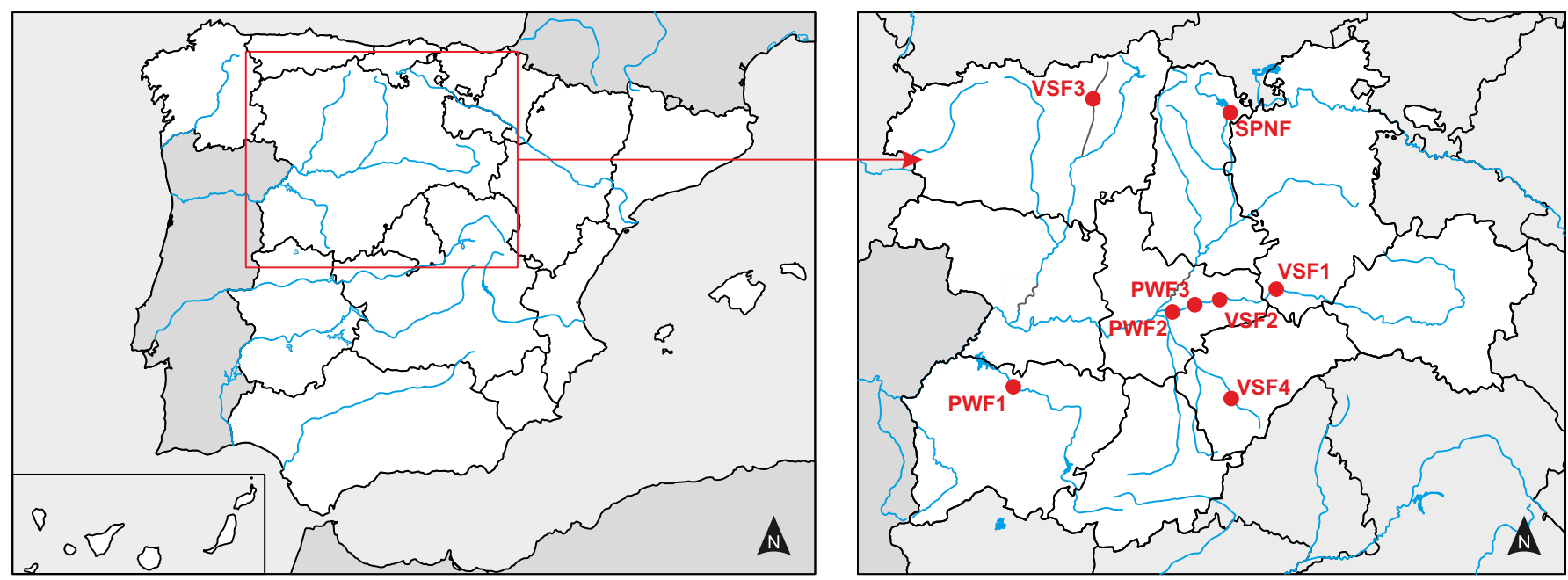

Fig. 3. Field cases location. Three types of fishways were studied in field: vertical slot fishway (VSF), pool and weir fishway (PWF) and steppool nature-like fishway (SPNF). Localization coordinates are defined in S2 Appendix.

\subsection{Experimental arrangement}

The following experimental procedure was used for all field experiments. The geometrical parameters of each structure were measured by topographic surveying with a total station Leica TC307 to a precision of $0.001 \mathrm{~m}$. Smaller details, such as orifice, notch and slot dimensions were measured by means of metal rulers to the same precision level.

The discharge of each scenario (different studied water level configurations, Tab. 2) through the structures was obtained by chemical gaging (precision of $0.004 \mathrm{~m}^{3} / \mathrm{s}$ ) using Rhodamine WT as tracer (Martínez, 2001). In cases where was possible, boundary conditions were artificially modified in the fishways in order to increase the number of studied scenarios. For example, when there was a gate situated upstream, different discharges were measured and, if possible, the water level downstream was also increased and decreased by modifying the section of the last control structures, creating new scenarios (Tab. 2) (see S2 Appendix for the geometrical information of the field cases and S3 Data Appendix for discharge, water levels and boundary conditions of each studied scenario).

Water levels were measured to a millimetric precision in each of the pools, by means of metal rulers installed where water surface was found more stable (downstream of the cross- wall and $0.40 \mathrm{~m}$ from the sidewall opposite to the notch $(0.15 B)$ or slot $(0.25 B)$ ). Water level oscillations were recorded for $8 \mathrm{~s}$ using a camera (Canon EOS 600D) with a sampling rate of $25 \mathrm{~Hz}$; in all cases after $\leq 2 \mathrm{~s}$ ( 50 samples) a stable mean value for the water level was obtained. For SPNF, due to the nature-like morphology and, thus, the absence of clear reference points for the metal rulers, water levels were measured in each of the corners of the pools using the total station. The mean value was used for calculations.

\subsection{Data fitting and validation}

Data from the literature review and field experiments were combined for each of the different stepped fishway types considered (VSF, PWF or SPNF) and within them for the different possible subtypes (e.g. VSF designs from No. 1 to No. 18 of Rajaratnam et al., 1986). Fishway subtypes are defined as fishways that, within the same type, have substantial differences in the configurations which result in a modification of the flow pattern. A global data table was created for each subtype with the necessary variables to study the proposed relations (i.e. type, subtype, $h_{2}, h_{1}, \Delta Z, Q$ and $b$ and $a$, for each of the connections (Fig. 1) if applicable). Curve fitting to calculate Villemonte's coefficients $\left(\beta_{0}\right.$ and $\beta_{1}$ in Eq. (4)) for each study case was undertaken in $\mathrm{R}$, release 3.3.1 (R Core Team, 2016). 
Table 2. Summary of the field scenarios for each fishway type (see S3 Data Appendix for detailed information about each studied scenario).

\begin{tabular}{|c|c|c|c|}
\hline Fishway & No. scenario & $Q\left(\mathrm{~m}^{3} / \mathrm{s}\right)$ & $h_{2 \text { final }}^{\prime}(\mathrm{m})$ \\
\hline \multirow{5}{*}{ VSF1 } & 1 & \multirow[t]{2}{*}{0.165} & 0.617 \\
\hline & 2 & & 0.700 \\
\hline & 3 & \multirow[t]{2}{*}{0.247} & 0.979 \\
\hline & 4 & & 1.029 \\
\hline & 5 & \multirow[t]{2}{*}{0.232} & 0.729 \\
\hline \multirow{3}{*}{ VSF2 } & 6 & & 0.858 \\
\hline & 7 & \multirow{2}{*}{0.276} & 0.816 \\
\hline & 8 & & 0.990 \\
\hline VSF3 & 9 & 0.315 & 1.170 \\
\hline VSF4 & 10 & \multirow{2}{*}{0.277} & 0.890 \\
\hline \multirow[t]{10}{*}{ VSF4 } & 11 & & 1.130 \\
\hline & 1 & \multirow{2}{*}{$0.077^{\mathrm{a}}$} & 0.881 \\
\hline & 2 & & 1.503 \\
\hline & 3 & 0.078 & 1.472 \\
\hline & 4 & 0.095 & 1.466 \\
\hline & 5 & \multirow{3}{*}{0.131} & 0.912 \\
\hline & 6 & & 1.475 \\
\hline & 7 & & 0.862 \\
\hline & 8 & \multirow[t]{2}{*}{$0.135^{\mathrm{a}}$} & 1.055 \\
\hline & 9 & & 1.467 \\
\hline \multirow[t]{10}{*}{ PWF1 } & 10 & \multirow{2}{*}{0.151} & 1.040 \\
\hline & 11 & & 1.488 \\
\hline & 12 & \multirow{3}{*}{0.195} & 1.097 \\
\hline & 13 & & 1.391 \\
\hline & 14 & & 1.083 \\
\hline & 15 & \multirow[t]{2}{*}{$0.242^{\mathrm{a}}$} & 1.256 \\
\hline & 16 & & 1.440 \\
\hline & 17 & \multirow{2}{*}{0.271} & 1.230 \\
\hline & 18 & & 1.479 \\
\hline & 19 & 0.337 & 1.255 \\
\hline PWF2 & 20 & 0.394 & 1.341 \\
\hline PWF3 & & 0.370 & 0.975 \\
\hline \multirow[t]{2}{*}{ PWF3.2 } & 21 & 0.187 & 1.221 \\
\hline & 1 & 0.206 & 0.583 \\
\hline \multirow[t]{2}{*}{ SPNF1 } & 2 & 0.329 & 0.600 \\
\hline & 3 & 0.455 & 0.593 \\
\hline
\end{tabular}

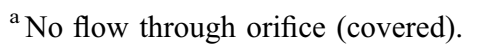

Following this, all fitted coefficients for each type and subtype of fishway were evaluated using root mean square errors (RMSEs) and determination coefficient $\left(R^{2}\right)$ as well as graphically. The proposed method was compared with other available methods of calculation for each fishway type. When different number of fitting parameters were involved between two different fishway calculation methods Bayesian Information Criterion (BIC) was used to compare the performance (Priestley, 1981; Kass and Wasserman, 1995).

In VSFs analysis, as an example, to demonstrate the applicability of the method here proposed, fitted equations were used to predict water level distributions (predicted data). In these cases, mean relative error (MRE) with respect to the measured real data (observed data), was used as descriptor of the achieved accuracy.

\section{Results and discussion}

\subsection{Vertical slot fishways}

Considering the number of references by fishway, VSFs seem to be one of the most studied and extended fishway types in the world. In 1986 and 1992 Rajaratnam et al. conducted the largest serial study to date of this type of structures. The VSF subtypes defined in these papers (18 in total) have been used as a reference for successive works (Puertas et al., 2004; Fuentes-Pérez et al., 2014) (for a complete description of the geometry of these subtypes please see the original references (Rajaratnam et al., 1986, 1992)). These authors defined dimensionless relationships to explain VSF performance (Eqs. (S4.1) and (S4.2) in S4 Appendix), including slope $(S)$ as a variable and only mean water level in the pool $\left(h_{0}\right)$ as a water level descriptor. This has been proven to be useful for uniform scenarios; however, it is invalid to estimate flow and water level distributions in non-uniform scenarios (Rajaratnam et al., 1986; Fuentes-Pérez et al., 2014).

Table 3 summarizes the number of observations, the origin of data as well as the fitted coefficients for equation (4) for each subtype of VSF defined by Rajaratnam et al. $(1986,1992)$ after literature and experimental data combination. In all cases, the use of equation (4) as discharge coefficient enables to explain precisely the observed variability as shown by the $R^{2}$ value. It is worth mentioning that the lower $R^{2}$ for subtype 1 may be explained by the higher variances of the four field studies included, compared to the laboratory experiments (Rajaratnam et al., 1986, 1992; Puertas et al., 2004) (Fig. 4a).

Figures $4 \mathrm{a}$ and $\mathrm{b}$ show the fits for some common VSF subtypes using Villemonte's equation. This equation is able to unify findings and observations of different studies. In addition, as shown in Figure 4a, the same fit could be used in subtypes 2 and 1 despite the presence of a small sill $(p=0.15 \mathrm{~m})$ in the former.

Although in equation (4), $S$ is not considered, the relation between $h_{2}$ and $h_{1}$ alone is able to account for the observed variance caused by different $S$ configurations in the same subtype. This can be explained by the fact that $S$ will determine the relation between both variables $\left(h_{2}\right.$ and $\left.h_{1}\right)$ under uniform conditions $\left(S \cdot(L+e)=\Delta Z=\Delta H=h_{1}-h_{2}\right.$, where $L$ is the length of the pool and $e$ is the thickness of the cross-wall) (Fuentes-Pérez et al., 2014). For this reason, it is possible to use the equation independently of the selected $S$, considering only the subtype and the observed water level distributions. It is worth mentioning that in cases where $S=0$ (fishways without slope) (Bice et al., 2017), the performance will always be nonuniform (Musall et al., 2015) and $\Delta H$ will only depend on the boundary conditions used. Although equation (4) allows its calculation, dimensionless relationships (Eqs. (S4.1) and (S4.2) in S4 Appendix) (Rajaratnam et al., 1986, 1992) will lead to an indetermination in these cases, as $S$ is a divider in equation (S4.1).

Figure $5 \mathrm{a}$ shows the potential of the proposed equation by correctly estimating the performances observed by Rajaratnam et al. (1986). In contrast to dimensionless relationships proposed by Rajaratnam et al. (1986), as $h_{2}$ and $h_{1}$ are involved in the proposed method, considering the geometrical parameters of the fishway, the bottom-up resolution of equation (1) and equation (4) (i.e. between two consecutive 
J.F. Fuentes-Pérez et al.: Knowl. Manag. Aquat. Ecosyst. 2017, 418, 23

Table 3. Summary of the coefficients for different VSF subtypes using Villemonte's discharge equation (Eq. (4)). $L$ and $B$ are the length and width of the pool respectively.

\begin{tabular}{|c|c|c|c|c|c|c|c|c|}
\hline Subtype & $\beta_{0}$ & $\beta_{1}$ & $R^{2}$ & RMSE & $L$ & $B$ & Data points & Data source \\
\hline $1^{\mathrm{a}}$ & 0.705 & 0.317 & 0.786 & 0.0285 & $10 b$ & $8 b$ & 161 & $\begin{array}{l}\text { Rajaratnam et al. }(1986,1992), \mathrm{FAO} / \mathrm{DVWK} \\
\text { (2002), Fuentes-Pérez et al. (2014) + } 4 \text { field cases }\end{array}$ \\
\hline $2^{b}$ & 0.671 & 0.326 & 0.971 & 0.0163 & $10 b$ & $8 b$ & 4 & Rajaratnam et al. $(1986,1992)$ \\
\hline 3 & 0.539 & 0.378 & 0.946 & 0.0181 & $10 b$ & $8 b$ & 45 & Rajaratnam et al. $(1986,1992)$ \\
\hline 4 & 1.296 & 0.387 & 0.956 & 0.0372 & $10 b$ & $8 b$ & 12 & Rajaratnam et al. $(1986,1992)$ \\
\hline 5 & 0.568 & 0.406 & 0.991 & 0.0066 & $10 b$ & $8 b$ & 9 & Rajaratnam et al. $(1986,1992)$ \\
\hline $6^{\mathrm{a}}$ & 0.858 & 0.574 & 0.900 & 0.0472 & $10 b$ & $8 b$ & 32 & Rajaratnam et al. (1986, 1992), Puertas et al. (2004) \\
\hline 7 & 0.495 & 0.337 & 0.937 & 0.0138 & $10 b$ & $8 b$ & 9 & Rajaratnam et al. $(1986,1992)$ \\
\hline 8 & 0.322 & 0.314 & 0.954 & 0.0089 & $5 b$ & $8 b$ & 12 & Rajaratnam et al. (1992) \\
\hline 9 & 0.312 & 0.292 & 0.945 & 0.0087 & $5 b$ & $4 b$ & 11 & Rajaratnam et al. (1992) \\
\hline 10 & 0.317 & 0.416 & 0.991 & 0.0051 & $5 b$ & $2.67 b$ & 14 & Rajaratnam et al. (1992) \\
\hline 11 & 0.719 & 0.458 & 0.997 & 0.0057 & $15 b$ & $8 b$ & 17 & Rajaratnam et al. (1992) \\
\hline 12 & 0.754 & 0.465 & 0.992 & 0.0220 & $15 b$ & $4 b$ & 15 & Rajaratnam et al. (1992) \\
\hline 13 & 1.162 & 0.531 & 0.987 & 0.0126 & $15 b$ & $2 b$ & 17 & Rajaratnam et al. (1992) \\
\hline 14 & 0.804 & 0.469 & 0.977 & 0.0159 & $10 b$ & $8 b$ & 19 & Rajaratnam et al. (1992) \\
\hline 15 & 0.718 & 0.468 & 0.990 & 0.0091 & $10 b$ & $8 b$ & 16 & Rajaratnam et al. (1992) \\
\hline $16^{\mathrm{a}}$ & 0.844 & 0.433 & 0.951 & 0.0243 & $10 b$ & $8 b$ & 30 & Rajaratnam et al. (1992), Puertas et al. (2004) \\
\hline 17 & 0.630 & 0.301 & 0.962 & 0.0089 & $10 b$ & $8 b$ & 9 & Rajaratnam et al. (1992) \\
\hline $18^{\mathrm{b}}$ & 0.740 & 0.311 & 0.933 & 0.0136 & $10 b$ & $8 b$ & 9 & Rajaratnam et al. (1992) \\
\hline
\end{tabular}

${ }^{\text {a }}$ Recommended by Rajaratnam et al. (1992).

${ }^{\mathrm{b}}$ Equal to subtype 1 but with a $p=0.15 \mathrm{~m}$.
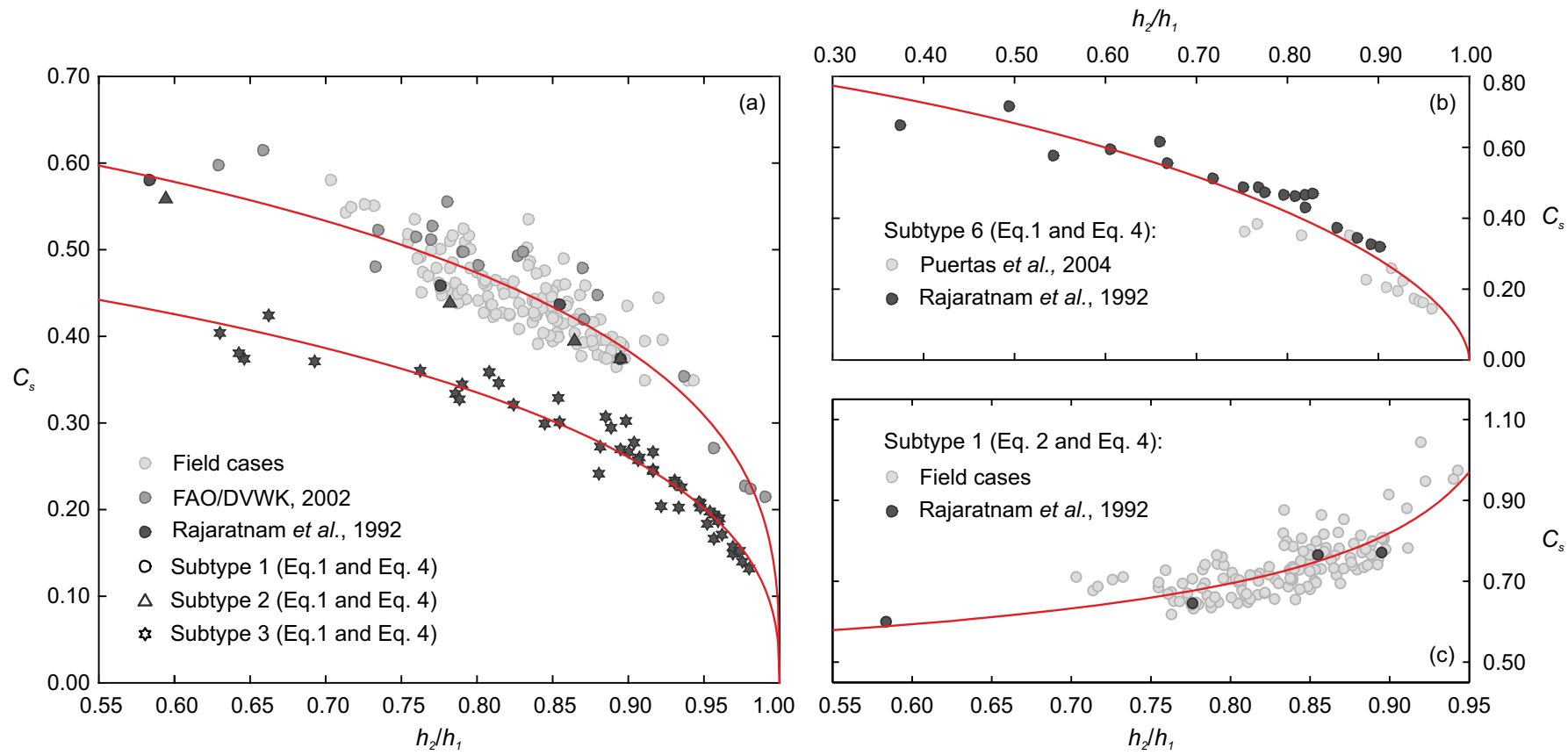

Fig. 4. Examples of discharge coefficient fits for most relevant (in terms of data points) VSF subtypes. (a) Subtypes 1-3 (fit coefficients and $R^{2}$ in Tab. 3). (b) Subtype 6 (fit coefficients and $R^{2}$ in Tab. 3). (c) Fit of equation (4) for subtype 1 to be used in equation (2) $\left(\beta_{0}=0.509, \beta_{1}=-0.248\right.$, $R^{2}=0.587$, RMSE $\left.=0.0458\right)$.

cross-walls, $i$ and $i+1$ (cf. Figs. S2.2 and S2.4 in S2 Appendix): $h_{2, i}^{\prime}=h_{1, i+1}^{\prime}-\Delta Z_{i, i+1} \quad$ and $h_{1, i}^{\prime}=h_{2, i}^{\prime}+\Delta H_{i}$ (Fuentes-Pérez et al., 2014)) can explain the water level distribution in each of the pools under uniform and non-uniform conditions accurately (Tab. 4).
The correct estimation of water level distribution is vital to assess the performance of fishways, as from this, other variables which are directly related with fish preferences and swimming abilities (Larinier, 2002a, 2002b), such as volumetric power dissipation $\left(V P D=\rho \cdot g \cdot \Delta H \cdot Q /\left(B \cdot L \cdot h_{0}\right)\right.$, where $\rho$ is the water 
density and $B$ is the width of the pool) (FAO/DVWK, 2002; Towler et al., 2015) or maximum velocity in the crosswall $\left(V_{\max }=\sqrt{2 \cdot g \cdot \Delta H}\right)$ (Rajaratnam et al., 1986; Larinier, $2002 b$ ) can be estimated. Therefore, this method will enable the analysis of the possible consequences in fish passage of different hydraulic scenarios and, thus, it will allow the preliminary evaluation of the passage and detection of possible problems during the whole hydrological period.
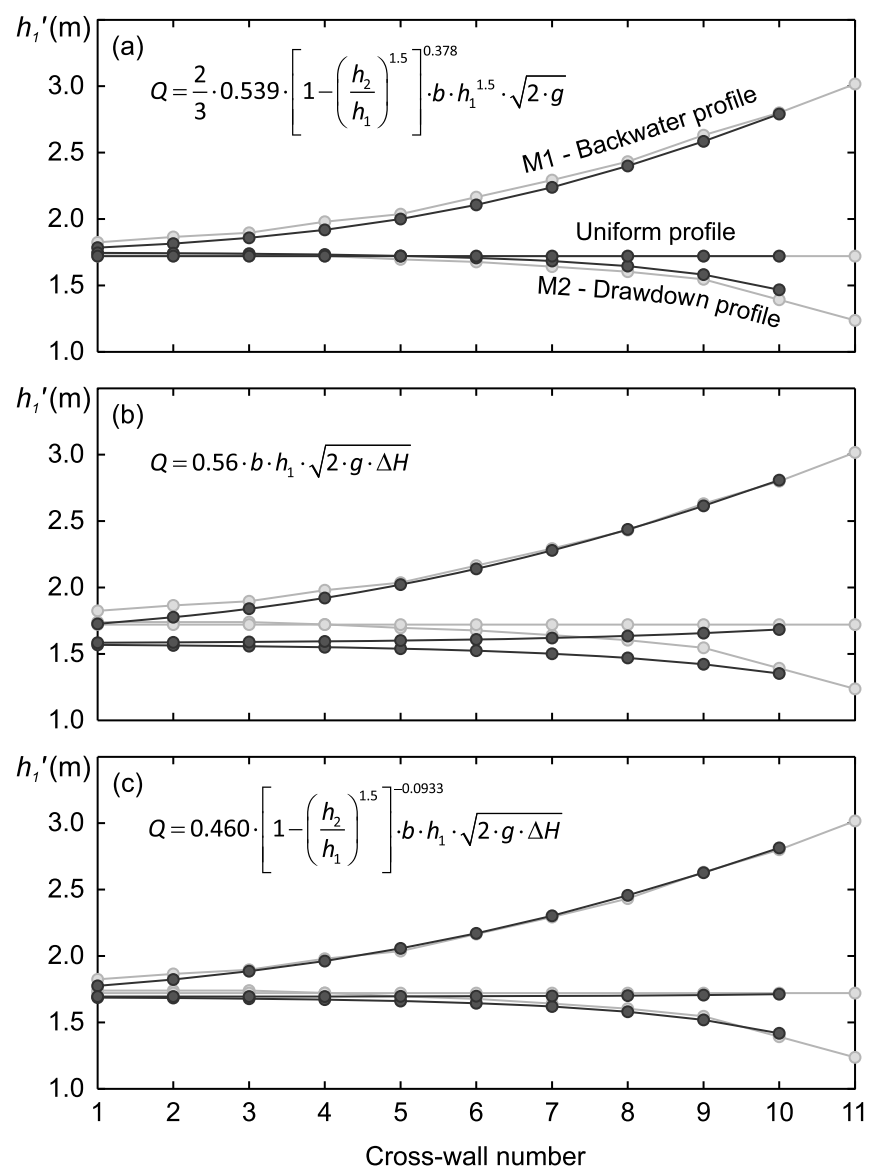

Fig. 5. Non-uniform performance in a VSF of subtype 3, scenario observed (grey) by Rajaratnam et al. (1986) and simulated (black) by different equation combinations. M1: $h_{2}=2.712 \mathrm{~m}$ and $Q=0.66 \mathrm{~m}^{3} / \mathrm{s}$; M2: $h_{2}=0.931 \mathrm{~m}$ and $Q=0.66 \mathrm{~m}^{3} / \mathrm{s}$; uniform: $h_{2}=1.416 \mathrm{~m}$ and $Q=0.66 \mathrm{~m}^{3} / \mathrm{s}$. (a) Equations (1) and (4). (b) Equation (2) and constant coefficient $(C=0.56)$. (c) Equations (2) and (4).
In recent years, different equations or equation combinations have been proposed to explain the performance of the discharge coefficient in VSFs under uniform and non-uniform scenarios (Krüger et al., 2010; Fuentes-Pérez et al., 2014; Marriner et al., 2016). However, all of them present limitations that can be overcome with the use of equation (4).

For instance, Krüger et al. (2010) proposed the use of a similar equation to equation (4) but allowing the constant exponent 1.5 to be adjusted for each VSF subtype (Eq. (S4.3) in S4 Appendix). This only provides slightly higher $R^{2}$ in the $46 \%$ of cases (in the $54 \%$ of cases Eq. (4) provides higher $R^{2}$ ); however, in the $96 \%$ of cases 1.5 is in the $95 \%$ of confident interval of the exponent, which consequently seems to indicate that the fit of this variable is unnecessary. Likewise, if the number of free parameters (three against two) is taken into account and the collected data is applied to fit both equations, equation (4) will produce better fits in $67 \%$ of studied cases $\left(\mathrm{BIC}_{\mathrm{Eq} .(4)}<\mathrm{BIC}_{\mathrm{Eq} \text {.(S4.3) }}\right)$ and in $40 \%$ of all cases the difference will not be significant $\left(\left|\mathrm{BIC}_{\mathrm{Eq} .(4)}-\mathrm{BIC}_{\mathrm{Eq} .(\mathrm{S} 4.3)}\right|<2\right)$, which seems to indicate an overfitting problem in the equation proposed by Krüger et al. (2010). Moreover, Villemonte's approach enables the comparison of different fishways, as $\beta_{0}$ and $\beta_{1}$ in equation (4) provide, directly, information about hydrodynamic performance. $\beta_{0}$ provides information about the horizontal asymptote to be reached by the fit and $\beta_{1}$ (indicative of the curvature of the fit) provides information about the evolution of the coefficient with the submergence.

In Fuentes-Pérez et al. (2014), as an alternative to the combination of equations (1) and (4), equation (2) together with equation (4) was suggested for flow estimation in VSFs (e.g. Figs. 4c and 5c). Equation (2) has been widely recommended by specialized references as it has a physical justification (Clay, 1995; Martínez de Azagra, 1999; Larinier, 2002b; Marriner et al., 2016) and as it collects part of the variability caused by the non-uniform performance itself (without Eq. (4)). This allows a better flow calculation than with equation (1) in the first states of non-uniformity when a constant discharge coefficient is used (Fig. 5b). However, as can be seen from Figures $4 c, 5 b, 5 c$ and Table 4, the use of equation (4) is also necessary to collect all the variability produced by non-uniformity and to accurately calculate the flow and water level distribution. When equation (4) is used, good results are expected with both equations (Tab. 4). Nevertheless, the use of equation (2) instead of equation (1), can also reduce the interpretability of equation (4), as the

Table 4. Mean relative error for equation combinations and scenarios represented in Figure 5.

\begin{tabular}{llccc}
\hline Scenario & Error $(\%)$ & Equation $(1)$ and equation $(4)$ & Equation $(2)$ and equation $(4)$ & Equation $(2)$ and $C=0.56$ \\
\hline \multirow{2}{*}{ Uniform } & $\varepsilon_{h 1}$ & 0.819 & 1.278 & 6.113 \\
& $\varepsilon_{\Delta H}$ & 0.557 & 0.885 & 4.492 \\
& $\varepsilon_{V P D}$ & 0.817 & 1.232 & 5.852 \\
M1 & $\varepsilon_{h 1}$ & 2.039 & 0.967 & 1.963 \\
& $\varepsilon_{\Delta H}$ & 10.702 & 10.464 & 10.295 \\
& $\varepsilon_{V P D}$ & 10.395 & 9.756 & 9.609 \\
M2 & $\varepsilon_{h 1}$ & 1.197 & 2.324 & 8.658 \\
& $\varepsilon_{\Delta H}$ & 3.852 & 3.323 & 4.722 \\
& $\varepsilon_{V P D}$ & 3.385 & 3.206 & 9.359 \\
\hline
\end{tabular}




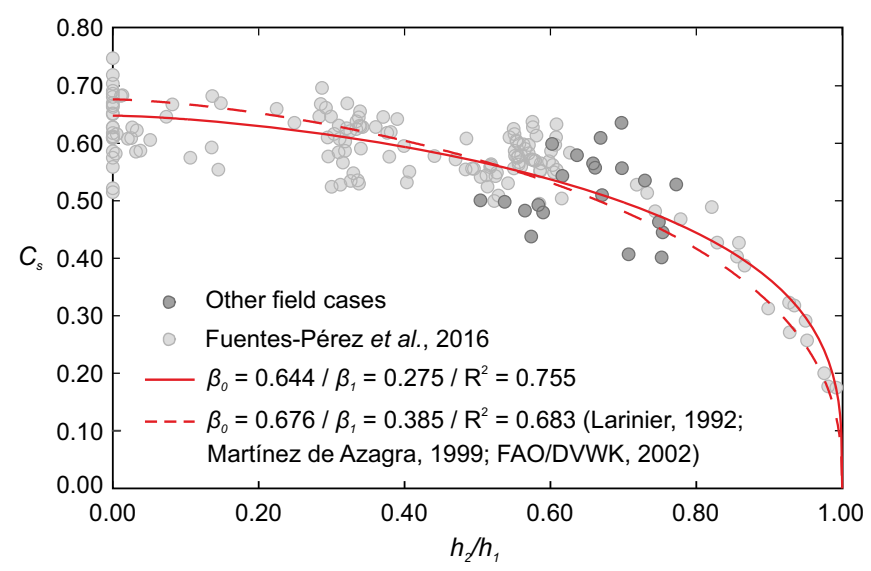

Fig. 6. $C_{s}$ fit for studied PWF and alternative methods proposed by specialized references. In total 180 data points were collected.

variability due to non-uniformity is distributed in two different equations (Eqs. (2) and (4)), instead of only one (Eq. (4)).

\subsection{Pool and weir fishways}

Villemonte's equation was originally proposed for submerged weirs and, therefore, it has been widely used to calculate the flow over PWF. Although Villemonte adjusted the equation for sharp-crested weirs with specific experimental conditions and suggested new fits for different conditions, in practice, the originally proposed coefficients have been indiscriminately used in PWFs (Larinier, 1992; Martínez de Azagra, 1999; FAO/DVWK, 2002). The utility of equation (4) and the convenience of specific fits for a PWF subtype has been previously shown in Fuentes-Pérez et al. (2016).

The notch of PWFs can perform under two different flow regimen conditions, plunging (or free flow) and streaming (or submerged flow), depending on the influence of $h_{2}$ over $h_{1}$ (Rajaratnam et al., 1988). In the first case, $h_{2}=0\left(h_{2}^{\prime}<p\right.$, see Fig. 2) allowing the free flow, while in the later performance $h_{2}>0\left(h_{2}^{\prime}>p\right.$, see Fig. 2) and, thus, $h_{2}$ slowdowns the flow due to $h_{1}$. These performances can be found independently or mixed within a fishway. Therefore, the proposed equations must be able to describe both possible conditions.

Usually, and for practical reasons, a constant discharge coefficient is used for notch in plunging performance (Larinier, 1992; Martínez de Azagra, 1999; FAO/DVWK, 2002). This is because the coefficient only changes significantly for low water levels over the sill which is not a typical performance of fishways (Rehbock, 1929; Ead et al., 2004; Fuentes-Pérez et al., 2016). For this reason, $\beta_{0}$ in equation (4) can be considered as a constant approximation of the free discharge coefficient (when free flow $h_{2} / h_{1}=0$ consequently $C_{s}=\beta_{0}$ ) and, thus, equation (4) can be used as a general descriptor of plunging and streaming performances. For studies focused on low discharges over fishways, and usually outside their operation range, the use of a variable $\beta_{0}$ is recommended (cf. Fuentes-Pérez et al. (2016)).

PWFs besides a notch also tend to have an orifice, as an alternative passage for fish fauna (Silva et al., 2009; Branco et al., 2013) or to facilitate fishway cleaning (Larinier, 2002b). Thus, the discharge of the orifice must be considered.
As previously shown, the $C_{o}$ for orifices will be constant. Therefore, 0.876 has been used for $C_{o}$ in all field scenarios to calculate the parameters of equation (4). This value is within the coefficient range recommended by specialized references (Martínez de Azagra, 1999; FAO/DVWK, 2002; Larinier, 2002b; Boiten and Dommerholt, 2006) and was calculated for the subtype under study in a systematic field study (Fuentes-Pérez et al., 2016). Nevertheless, appropriate specific constant $C_{o}$ values for submerged orifices can be found in Brater et al. (1996).

Considering all of the above, i.e. constant $C_{o}$ and $\beta_{0}$, Figure 6 shows the $C_{s}$ distribution for the studied PWFs cases. As shown in the figure, considering the $\beta_{1}$ proposed by Villemonte $\left(\beta_{1}=0.385\right)$, as suggested by specialized references, and fitting only $\beta_{0}$, provides a good result; however as recommended by Villemonte, a specific fit offers significant better results $\left(R^{2}\right.$ of 0.755 versus 0.683 , RMSE 0.0474 versus 0.0538 and $\left.\mathrm{BIC}_{\text {Eq.(4) }}<\mathrm{BIC}_{\text {Eq.(4), } \beta 1=0.385}\right)$.

The studied field cases involve a $b$ value for the notch in the range of $0.20-0.40 \mathrm{~m}$ and a side length for the square orifice in the range of $0.15-0.25 \mathrm{~m}$ (Tab. S2.2 in S2 Appendix), which demonstrates the utility of the fit for different notch dimensions. However, all the studied cases have similar configuration (i.e. the flow pattern is similar and therefore they can be considered the same subtype) and, thus, as for the VSF, new fits are recommended for different possible subtypes.

A common alternative calculation to the one described above are the dimensionless relations proposed by Rajaratnam et al. (1988) (Eqs. (S4.4) and (S4.5) in S4 Appendix). These equations have been studied and validated in a number of studies (Ead et al., 2004; Yagci, 2010). However, each of the equations proposed by Rajaratnam et al. (1988) is defined for a possible regimen (plunging or streaming), not allowing mixed scenarios. Furthermore, as the dimensionless relations proposed by the same authors for VSFs, they depend on $S$ and they only consider $h_{0}$ as water level descriptor, which does not allow their use under non-uniform conditions and generate indeterminations in some cases (e.g. $S=0)$.

\subsection{Step-pool nature-like fishway}

Most of hydraulic studies on SPNFs have focused on the evaluation of velocity, dissipated energy or friction factors (Pagliara and Chiavaccini, 2006; Wang and Hartlieb, 2011; Oertel and Schlenkhoff, 2012) and, there are no specific studies on discharge and discharge coefficients.

Despite the lack of published studies, design guidelines recommend the use of discharge and discharge coefficient equations. For instance, FAO/DVWK (2002) and Larinier et al. (2006) recommend the use of the equation for submerged flow in broad-crested weirs. This consists of the use of an equation similar to equation (1) together with a drowned-flow reduction factor $(\sigma)$ (Schröder, 1994) (Eqs. (S4.6) and (S4.7) in S4 Appendix) and a reduction constant coefficient $(\mu)$ that depends on the geometry of the stones (range from 0.5 to 0.8 if they are sharp-edged or rounded stones respectively (FAO/ DVWK, 2002)). In the same way, Hegberg et al. (2001) proposed the use of the equation for sharp-crested weirs of Villemonte (Eqs. (1) and (4) with $\beta_{1}=0.385$ and a calibrated $\left.\beta_{0}\right)$. Likewise, due to the small sills that are presented in notches in these kind of configurations (mean $p=0.166 \mathrm{~m}$ for 


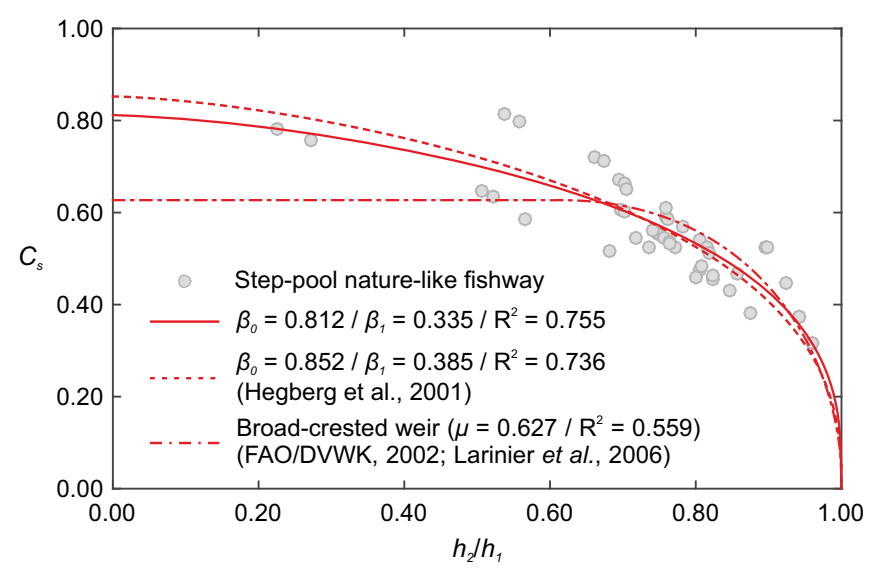

Fig. 7. Fits for the studied SPNF and alternative methods proposed by specialized references. In total 45 data points were collected.

the studied case), it is a common practice (FAO/DVWK, 2002; Larinier et al., 2006) to consider for all type of connections same discharge coefficient (i.e. same exponents and coefficients in the discharge coefficient equation).

Figure 7 shows both methods fitted for the field case data in a SPNF together with the fit of Villemonte's equation, where both parameters involved $\left(\beta_{0}\right.$ and $\left.\beta_{1}\right)$ have been recalculated given the different settings from the ones originally used by the author. As shown by the fit for the broad-crested weir method (FAO/DVWK, 2002; Larinier et al., 2006), it assumes that for situations with $h_{2} / h_{1}<0.614$ there is no influence of $h_{2}$ in the flow, which does not fit the observed data distribution $(\mathrm{RMSE}=0.3433)$.

When comparing the $\beta_{1}$ fitted with that proposed in Villemonte's experiments, as recommended by Hegberg et al. (2001), fitting both parameters provide better significant results (RMSE of 0.0573 versus 0.0583 and $\mathrm{BIC}_{\mathrm{Eq} .(4)}<\mathrm{BIC}_{\mathrm{Eq}}$ (4), $\beta 1=0.385$ ) (Fig. 7). However, the difference is smaller than the one observed for other fishway types (Figs. 4 and 6). This could be explained by the smaller slopes, longer pool length and less turbulence of SPNFs compared with other fishway types, which are closer to the experimental conditions used by Villemonte (without slope $(S=0)$ and $h_{1}$ and $h_{2}$ measured outside the influence of turbulence). It is noteworthy that the presented result needed to be further studied as only data from one field study has been considered.

In addition, further considerations should be taken into account when overtopping flows occur. In these cases, the cross-walls are completely submerged and the fishway behaves like a channel with continuous roughness in the bottom. Under these conditions, the flow is usually explained by means of relative energy dissipation and friction factors in SPNFs (Oertel and Schlenkhoff, 2012). These variables will depend on the configuration of the boulder arrangements (boulder size, shape and concentration), the slope (Oertel and Schlenkhoff, 2012; Cassan and Laurens, 2016) and also on the submergence ratio (Oertel and Schlenkhoff, 2012; Baki et al., 2014). Likewise, more studies under these experimental conditions are necessary to evaluate the performance of the proposed equations. Nevertheless, these conditions can always be controlled with an adequate design or a control gate upstream of the facility.

\section{Summary and conclusions}

This article shows how a single equation, Villemonte's equation, can be used to calculate the flow and water level distribution of the most common type of stepped fishways under different hydrodynamic conditions, which provides a standardized method for the design and calibration of the performance of these structures. In addition, compared to more extended methods, this equation has shown a better performance not only due to its simplicity, better fit or capacity to unify the different references, but also due to its ability to explain uniform and non-uniform scenarios with a single equation.

In general, in order to obtain an optimal solution, it seems necessary to estimate both free parameters involved in equation (4) $\left(\beta_{0}\right.$ and $\left.\beta_{1}\right)$, which is understandable given the different experimental conditions used by Villemonte in his original studies.

The possibility of modeling water level distribution in variable hydrodynamic scenarios provides us with the opportunity to study the variation of hydraulic parameters (e.g. VPD and $\left.V_{\max }\right)$ within the fishway and ensures the fulfillment of fish fauna preferences in different flow conditions and during the whole hydrological period. Furthermore, if incompatibilities with fish fauna are detected, possible solutions can be tested using the proposed equations. This possibility of optimization in both design and operation will contribute to ensure the longitudinal connectivity in rivers and, thus, facilitate fish migration and species conservation.

In future studies, it would be interesting to validate Villemonte's methodology in other subtypes of fishway, for instance those with non-rectangular shape connections (e.g. triangular, parabolic, etc.).

\section{Supplementary Material}

Appendix S1. Search strategy.

Appendix S2. Field case studies.

Appendix S3. Data Appendix.

Appendix S4. Auxiliary equations.

The Supplementary Material is available at http://www. kmae-journal.org/10.1051/kmae/2017013/olm.

\section{Nomenclature}

$a$

B

b

$C_{o}$

$C_{s}$

e

$g$

$H$

$h_{0}$

$h_{1}$

$h_{2}$ orifice height (m)

pool width (m)

notch, slot or orifice width (m)

discharge coefficient for orifices (dimensionless)

discharge coefficient for slots and notches (dimensionless)

cross-wall thickness (m)

acceleration due to gravity $\left(\mathrm{m} / \mathrm{s}^{2}\right)$

total height of the transversal obstacle (m)

mean water level of the flow in the pool (m)

mean water level of the flow in the pool upstream of the cross-wall measured from the sill (m)

mean water level of the flow in the pool downstream of the cross-wall measured from the sill $(\mathrm{m})$ 


\begin{tabular}{|c|c|}
\hline$h_{1}^{\prime}$ & $\begin{array}{l}\text { mean water level of the flow in the pool upstream of } \\
\text { the cross-wall }\left(h_{1}^{\prime}=h_{1}+p\right)(\mathrm{m})\end{array}$ \\
\hline$h_{2}^{\prime}$ & $\begin{array}{l}\text { mean water level of the flow in the poo } \\
\text { downstream of the cross-wall }\left(h_{2}^{\prime}=h_{2}+p\right)(\mathrm{m})\end{array}$ \\
\hline & cross-wall index \\
\hline$L$ & pool length (m) \\
\hline$P$ & sill height $(\mathrm{m})$ \\
\hline$Q_{1}$ & free-flow discharge due to $h_{1}\left(\mathrm{~m}^{3} / \mathrm{s}\right)$ \\
\hline$Q_{2}$ & counter-flow discharge due to $h_{2}\left(\mathrm{~m}^{3} / \mathrm{s}\right)$ \\
\hline$Q_{\text {design }}$ & $\begin{array}{l}\text { theoretical discharge or flow, as calculated in the } \\
\text { fishway design project }\left(\mathrm{m}^{3} / \mathrm{s}\right)\end{array}$ \\
\hline$Q$ & discharge or flow rate $\left(\mathrm{m}^{3} / \mathrm{s}\right)$ \\
\hline$R^{2}$ & determination coefficient (dimensionless) \\
\hline$S$ & slope $(\mathrm{m} / \mathrm{m})$ \\
\hline$V_{\max }$ & elocity $(\mathrm{m} / \mathrm{s})$ \\
\hline$V P D$ & sipation $\left(\mathrm{W} / \mathrm{m}^{3}\right)$ \\
\hline$\beta_{0}, \beta_{1}$ & dimensionless coefficients for equation (4) \\
\hline$\Delta H$ & $\begin{array}{l}\text { water level difference between pools or head drop } \\
\left(\Delta H=h_{1}-h_{2}\right)(\mathrm{m})\end{array}$ \\
\hline$\Delta Z$ & topographic difference between cross-walls (m) \\
\hline$\rho$ & er $\left(\mathrm{kg} / \mathrm{m}^{3}\right)$ \\
\hline$\sigma$ & $\begin{array}{l}\text { reduction factor for broad-crested weirs (dime } \\
\text { sionless) }\end{array}$ \\
\hline$\mu$ & $\begin{array}{l}\text { reduction constant coefficient for broad-creste } \\
\text { weirs (dimensionless) }\end{array}$ \\
\hline
\end{tabular}

Acknowledgements. The authors would like to thank the owners and staff of the hydropower plants and fish farms associated to field cases (SAVASA, Iberdrola, Molinos de Castilla, Comunidad de Regantes de El Carracillo, Junta de Castilla y León, Piscifactoría de Campoo) for their collaboration during the experimental procedures, as well as Dr. Sara Fuentes-Pérez for her editorial advice and active participation in the revision of this paper.

\section{References}

Baki ABM, Zhu DZ, Rajaratnam N. 2014. Mean flow characteristics in a rock-ramp-type fish pass. J Hydraul Eng 140: 156-168.

Bermúdez M, Puertas J, Cea L, Pena L, Balairón L. 2010. Influence of pool geometry on the biological efficiency of vertical slot fishways. Ecol Eng 36: 1355-1364.

Bice CM, Zampatti BP, Mallen-Cooper M. 2017. Paired hydraulically distinct vertical-slot fishways provide complementary fish passage at an estuarine barrier. Ecol Eng 98: 246-256.

Boiten W, Dommerholt A. 2006. Standard design of the Dutch pool and orifice fishway. Int J River Basin Manag 4: 219-227.

Branco P, Santos JM, Katopodis C, Pinheiro A, Ferreira MT. 2013. Pool-type fishways: two different morpho-ecological cyprinid species facing plunging and streaming flows. PLOS ONE 8: e65089.

Brater EF, King HW, Lindell JE, Wei CY. 1996. Handbook of hydraulics. Boston, MA, USA: McGraw Hill.

Cassan L, Laurens P. 2016. Design of emergent and submerged rockramp fish passes. Knowl Manag Aquat Ecosyst 45: 417.

Clay CH. 1995. Design of fishways and other fish facilities. Ottawa, Canada: CRC Press.

Ead SA, Katopodis C, Sikora GJ, Rajaratnam N. 2004. Flow regimes and structure in pool and weir fishways. J Environ Eng Sci 3: 379-390.
FAO/DVWK. 2002. Fish passes: design, dimensions, and monitoring. Rome, Italy: FAO, $119 \mathrm{p}$.

Fuentes-Pérez JF, Sanz-Ronda FJ, Martínez de Azagra Paredes A, García-Vega A. 2014. Modeling water-depth distribution in vertical-slot fishways under uniform and nonuniform scenarios. J Hydraul Eng 140: 6014016.

Fuentes-Pérez JF, Sanz-Ronda FJ, Martínez de Azagra-Paredes A, García-Vega A, Martínez de Azagra A, García-Vega A. 2016. Nonuniform hydraulic behavior of pool-weir fishways: a tool to optimize its design and performance. Ecol Eng 86: 5-12.

Hegberg CH, Jacobs S, Schlindwein PA, Cohen SJ. 2001. Fish passage in urban streams. Part 2: Natural channel design methods. Wetl Eng River Restor 1-12.

Kass RE, Wasserman L. 1995. A reference Bayesian test for nested hypotheses and its relationship to the Schwarz criterion. J Am Stat Assoc 90: 928-934.

Krüger F, Heimerl S, Seidel F, Lehmann B. 2010. Ein Diskussionsbeitrag zur hydraulischen Berechnung von Schlitzpässen. Wasser Wirtschaft 3: 31-36.

Larinier M. 1992. Passes à bassins successifs, prébarrages et rivières artificielles. Bull Fr Pêche Piscic 45-72: 326-327.

Larinier M. 2002a. Biological factors to be taken into account in the design of fishways, the concept of obstructions to upstream migration. Bull Fr Pêche Piscic 364: 28-38.

Larinier M. 2002b. Pool fishways, pre-barrages and natural bypass channels. Bull Fr Pêche Piscic 364: 54-82.

Larinier M, Courret D, Gomes P. 2006. Guide technique pour la conception des passes à poissons "naturelles". Rapport GHAAPPE RA.06.05-V1, Agence de 1'Eau Adour Garonne, Compagnie Nationale du Rhône, Conseil Supérieur de la Pêche, Groupe d'Hydraulique Appliquée aux Aménagements Piscicoles et à la Protection de l'Environnement, Institut de mécanique des fluides de Toulouse, $66 \mathrm{p}$.

Lucas MC, Baras E, Thom TJ, Duncan A, Slavík O. 2001. Migration of freshwater fishes. Oxford, UK: Wiley Online Library, $440 \mathrm{p}$.

Marriner BA, Baki ABM, Zhu DZ, Cooke SJ, Katopodis C. 2016. The hydraulics of a vertical slot fishway: a case study on the multispecies Vianney-Legendre fishway in Quebec, Canada. Ecol Eng 90: 190-202.

Martínez E. 2001. Hidráulica fluvial: principios y práctica. Madrid, Spain: Bellisco.

Martínez de Azagra A. 1999. Escalas para peces. Palencia, Spain: ETSIIAA, Universidad de Valladolid.

Moher D, Liberati A, Tetzlaff J, Altman DG, The PRISMA Group. 2009. Preferred reporting items for systematic reviews and metaanalyses: The PRISMA statement. PLoS Med 6: e1000097.

Musall M, Oberle P, Carbonell-Baeza R, Fuentes-Pérez JF, Tuhtan JA, Nestmann F. 2015. Beitrag zu detaillierten Analysen der Hydraulik von Schlitzpässen. Wasser Wirtschaft 7/8: 67-71.

Nilsson C, Reidy CA, Dynesius M, Revenga C. 2005. Fragmentation and flow regulation of the world's large river systems. Science 308: 405-408.

Oertel M, Schlenkhoff A. 2012. Crossbar block ramps: flow regimes, energy dissipation, friction factors, and drag forces. J Hydraul Eng 138: 440-448.

Pagliara S, Chiavaccini P. 2006. Flow resistance of rock chutes with protruding boulders. J Hydraul Eng 132: 545-552.

Poleni G. 1717. De motu aquae mixto libri duo, Iosephi Comini, Patavii.

Priestley MB. 1981. Spectral analysis and time series. London, UK: Academic Press, 890 p.

Puertas J, Pena L, Teijeiro T. 2004. Experimental approach to the hydraulics of vertical slot fishways. J Hydraul Eng 130: 10-23. 
R Core Team. 2016. R: a language and environment for statistical computing. Vienna, Austria: $\mathrm{R}$ Foundation for Statistical Computing.

Rajaratnam N, Van der Vinne G, Katopodis C. 1986. Hydraulics of vertical slot fishways. J Hydraul Eng 112: 909-927.

Rajaratnam N, Katopodis C, Mainali A. 1988. Plunging and streaming flows in pool and weir fishways. J Hydraul Eng 114: 939-944.

Rajaratnam N, Katopodis C, Mainali A. 1989. Pool-orifice and poolorifice-weir fishways. Can J Civil Eng 16: 774-777.

Rajaratnam N, Katopodis C, Solanki S. 1992. New designs for vertical slot fishways. Can J Civil Eng 19: 402-414.

Rehbock T. 1929. Wassermessung mit scharfkantigen Überfallwehren. $Z$ Ver dtsch Ing 73: 817-823.

Santos JM, Branco P, Katopodis C, Ferreira T, Pinheiro A. 2014. Retrofitting pool-and-weir fishways to improve passage performance of benthic fishes: effect of boulder density and fishway discharge. Ecol Eng 73: 335-344.

Sanz-Ronda FJ, Bravo-Cordoba FJ, Fuentes-Pérez JF, Castro-Santos T. 2016. Ascent ability of brown trout, Salmo trutta, and two Iberian cyprinids - Iberian barbel, Luciobarbus bocagei, and northern straight-mouth nase, Pseudochondrostoma duriense - in a vertical slot fishway. Knowl Manag Aquat Ecosyst 417: 10.

Schröder RCM. 1994. Technische Hydraulik: Kompendium für den Wasserbau. Berlin, Heidelberg: Springer-Verlag, 308 p.
Silva AT, Santos JM, Franco AC, Ferreira MT, Pinheiro AN. 2009. Selection of Iberian barbel Barbus bocagei (Steindachner, 1864) for orifices and notches upon different hydraulic configurations in an experimental pool-type fishway. $J$ Appl Ichthyol 25: 173-177.

Tarrade L, Pineau G, Calluaud D, Texier A, David L, Larinier M. 2011. Detailed experimental study of hydrodynamic turbulent flows generated in vertical slot fishways. Environ Fluid Mech 11: 1-21.

Torricelli E. 1644. Opera geometrica. Florence, Italy: Amadoro Massa \& Lorenzo de Landis.

Towler B, Mulligan K, Haro A. 2015. Derivation and application of the energy dissipation factor in the design of fishways. Ecol Eng 83: 208-217.

Villemonte JR. 1947. Submerged-weir discharge studies. Eng News Rec 139: 866-869.

Wang RW, Hartlieb A. 2011. Experimental and field approach to the hydraulics of nature-like pool-type fish migration facilities. Knowl Manag Aquat Ecosyst 400: 1-18.

Wang RW, David L, Larinier M. 2010. Contribution of experimental fluid mechanics to the design of vertical slot fish passes. Knowl Manag Aquat Ecosyst 396: 1-21.

Wu S, Rajaratnam N, Katopodis C. 1999. Structure of flow in vertical slot fishway. J Hydraul Eng 125: 351-360.

Yagci O. 2010. Hydraulic aspects of pool-weir fishways as ecologically friendly water structure. Ecol Eng 36: 36-46.

Cite this article as: Fuentes-Pérez JF, García-Vega A, Sanz-Ronda FJ, Martínez de Azagra Paredes A. 2017. Villemonte's approach: a general method for modeling uniform and non-uniform performance in stepped fishways. Knowl. Manag. Aquat. Ecosyst., $418,23$. 